\title{
Histamine and Delirium: Current Opinion
}

\author{
Paul L. Chazot ${ }^{1 *}$, Laura Johnston', Edel Mcauley² and Stephen Bonner ${ }^{2}$ \\ ${ }^{1}$ Department of Biosciences, Durham University, Durham, United Kingdom, ${ }^{2}$ Intensive Care, South Tees Hospitals NHS \\ Foundation Trust, The James Cook University Hospital, Middlesbrough, United Kingdom
}

Delirium is a very common, but refractory clinical state, notably present in intensive care and in the growing aging community. It is characterized by fluctuating disturbances in a number of key behavioral features, namely cognition, mood, attention, arousal, and self-awareness. Histamine is arguably the most pleotropic neurotransmitter in the human brain, and this review provides a rationale, and proposes that this neuroactive amine plays a role in modulating the characteristic features of delirium. While centrally permeable $\mathrm{H}_{1}$ and $\mathrm{H}_{2}$ histamine receptor antagonists have pro-delirium potential, we propose that centrally permeable $\mathrm{H}_{3}$ histamine receptor antagonists may provide an exciting new strategy to combat delirium. The Histamine $\mathrm{H}_{4}$ receptor may also have an indirect inflammatory neuroglial role which requires further exploration.

Keywords: histamine, $\mathrm{H3}$ receptor, delirium, CNS, autoreceptor, heteroreceptor

\section{INTRODUCTION}

\section{OPEN ACCESS}

Edited by:

Mitsunobu Mio,

Shujitsu University, Japan

Reviewed by:

Estefanía Moreno,

University of Barcelona, Spain

Enric I. Canela,

University of Barcelona, Spain

*Correspondence:

Paul L. Chazot

paul.chazot@durham.ac.uk

Specialty section:

This article was submitted to Experimental Pharmacology

and Drug Discovery,

a section of the journal

Frontiers in Pharmacology

Received: 17 January 2019

Accepted: 11 March 2019

Published: 09 April 2019

Citation:

Chazot PL, Johnston L, Mcauley E and Bonner S (2019) Histamine and Delirium: Current Opinion. Front. Pharmacol. 10:299. doi: 10.3389/fphar.2019.00299

\section{What Is Delirium?}

Delirium is a very common, but refractory clinical state, notably commonly present in intensive care and in the growing aging community, with occurrence rates ranging from 14 to $56 \%$, and hospital mortality rates ranging from 25 to $33 \%$ (Leslie and Inouye, 2011). It is characterized by fluctuating disturbances in arousal, attention, cognition, mood, and self-awareness, which can arise acutely, either in the absence of prior intellectual impairment or superimposed on chronic intellectual impairment in the growing aging population. The rise and development of delirium has been associated with increased morbidity, persistent functional decline, increased nursing time, higher hospital costs, increased length of hospital stay, and higher rates of nursing car home placement. Worryingly, delirium is a common, serious, and refractory source of mortality in intensive and community care across the age range, but is only recently being addressed in the United Kingdom, Europe and worldwide (Leslie and Inouye, 2011). Delirium in older hospitalized patients is of particular concern because patients aged 65 years and over currently account for more than half of all days spent in hospital care.

Delirium is a neurobehavioral syndrome caused by dysregulation of neuronal activity often secondary to serious systemic disturbances. Over time, a number of theories have been proposed in an attempt to explain the processes leading to the development of delirium (Maldonado, 2015; Herling et al., 2018). Each proposed complementary theory has focused on combinations of specific mechanisms or pathological processes (e.g., dopamine excess or acetylcholine deficiency, inflammatory responses), observational qualitative evidence (e.g., sleep deprivation, aging), or empirical scientific data (e.g., specific pharmacological agents such as opioids) or intraoperative hypoxia state association with postoperative delirium) (Maldonado, 2013; Egberts et al., 2018). The literature suggests that many factors or mechanisms included in these theories lead to a final common outcome associated with an alteration in neurotransmitter synthesis, function, and/or availability that triggers the complex behavioral and cognitive changes reported in delirium. In general, 
the most commonly described neurochemical changes associated with delirium include deficiencies in acetylcholine and/or melatonin, together with excess in glutamate and monoamines dopamine and noradrenalin, and bi-directional activity alterations (e.g., decreased or increased activity, depending on delirium presentation and trigger) in serotonin, $\gamma$-aminobutyric acid (GABA) and/or, importantly, histamine (Maldonado, 2013). The unknown nature of etiology for most types of delirium and the complete lack of placebo-controlled Randomized Controlled drug Trials, the lack of any FDA-approved drug treatment for delirium and the wide ranging nature of drugs with multiple chemical neurotransmitter pathways affected (variable across NHS Trust hospitals) used to treat it is clearly a major problem. Furthermore the lack of effective non-pharmacological approaches is also problematical (Wade et al., 2015, 2019; Richards-Belle et al., 2018) Without understanding more about the underlying nature of the pathways involved how can we hope to effectively and rationally treat it?

In this short commentary, we offer a rationale for a new pharmacological strategy to combat delirium. We propose that central histamine is a significant player in all of the clinical features of delirium; while $\mathrm{H}_{1}$ and $\mathrm{H}_{2}$ histamine-targeted antihistamines should be treated with care, a centrally acting histamine $\mathrm{H}_{3}$ receptor antagonist, with appropriate diurnal pharmacokinetic properties, may provide a novel and effective strategy for preventing or combatting delirium. We discuss the key evidence base and potential mechanisms underpinning these proposals and clinical implications.

\section{HISTAMINE AND ANATOMICAL FRAMEWORK RELEVANCE TO DELIRIUM COGNITION, MOOD AND WAKEFULLNESS}

Arousal stems from the wakefulness of a person and awareness is the individual's ability to perceive his/her environment. In both these behavioral states, histamine has a primary role to play. Diminished alertness, delayed reaction times, and somnolence are common manifestations of allergy treatments with use of classic first-generation (CNS-permeant) anti-histamines, thus evidencing that histamine is required for arousal/wakefulness and awareness/attention. The evidence became stronger with the report that histidine decarboxylase (HDC) knockout mice, which lack histamine, display increased paradoxical sleep, sleep-wake cycle modifications, and are unable to remain awake under diurnal high vigilance (narcolepsy) (Parmentier et al., 2002). The mammalian, including human, waking state is maintained by continual activation of neuromodulatory aminergic neurotransmitters [dopamine, noradrenaline (NA), acetylcholine and notably histamine], hypocretin/orexinergic (Oxergic), and selective excitatory glutamatergic and inhibitory GABAergic pathways (Korotkova et al., 2005; Yu et al., 2018). Cortical activation is one of the physiological signs of wakefulness and requires robust cholinergic, noradrenergic, serotonergic and, importantly, histaminergic tones. Histamine controls these features through the extensive influence of ascending branches from the tuberomammillary nucleus (TMN) in the hypothalamus to all parts of the brain, including the prefrontal cerebral cortex, various limbic regions and the basal ganglia ( $Y u$ et al., 2018). Monoaminergic neurons comprising noradrenergic (locus coeruleus: LC), serotonergic (raphe nuclei, RN) and histaminergic (TMN) neurons project to the cerebrocortex, thalamus and brainstem are known together as the center of sleep regulation (Oh et al., 2018; Yu et al., 2018). Furthermore, Oxergic cell bodies in the hypothalamus densely project to LC, TM and RN, which suggests a strong link between monoaminergic and Oxergic neurons, again in the control of wakefulness. It is well established that the Oxergic wakeactive neurons provide a major excitatory drive onto TMN histamine neurons (Lin et al., 2011), and this could be a key way that orexin promotes arousal, through amplifying its effects via the histaminergic system. During the wake state, TMN histamine/GABA-ergic neurons are co-active in parallel and their ascending histamine/GABA fibers release histamine and GABA into the prefrontal cortex (PFC), neocortex (Ctx) and striatum (Str) (Lin et al., 2011). Glutamatergic pyramidal neurons in the PFC send excitatory projections back to the histamine neurons in the TMN, reinforce wakefulness, attention and consciousness (Lin et al., 2011). The Histamine-GABA-ergic neurons are silenced during Non-REM sleep by preoptic GABAergic neurons. Histamine-only projections from the TMN also excite cholinergic neurons into the basal forebrain, and the axons of these excited cholinergic neurons release acetylcholine throughout the cortex (the fundamental basis for high attention together with productive cognitive function). We suggest that when the brain is exposed to these neuromodulators appropriately, we are wakeful, attentive and conscious, importantly, without delirium. This this overall neuronal anatomical framework provides the mechanistic basis for the influence of histamine upon delirium, through autoand hetero-presynaptic and postsynaptic functions, respectively.

\section{HISTAMINE RECEPTOR SUBTYPE-DEPENDENT EFFECTS}

Histamine elicits its physiological action via four G-protein couple receptor (GPCR subtypes, namely $\mathrm{H}_{1}, \mathrm{H}_{2}, \mathrm{H}_{3}$, and $\mathrm{H}_{4}$ receptors, expressed widely and differentially throughout the body, including the CNS (reviewed in Panula et al., 2015). In terms of the brain, $\mathrm{H}_{1}, \mathrm{H}_{2}, \mathrm{H}_{3}$ receptors play clear roles in neuronal function, post- and pre-synaptically, and, interestingly, the $\mathrm{H}_{4} \mathrm{R}$ appears to influence neuronal function indirectly through modulating activated microglia (Zhou et al., 2018). Histamine driven $\mathrm{H}_{1}$ and $\mathrm{H}_{2}$ receptor-mediated actions are mostly excitatory, while $\mathrm{H}_{3}$ receptors act as inhibitory autoand heteroreceptors (Panula et al., 2015). Histamine-mediated excitation was blocked by a CNS-permeable $\mathrm{H}_{1}$ receptor antagonist, mepyramine, in $78 \%$ of cells and by cimetidine, a CNS-permeable $\mathrm{H}_{2}$ receptor antagonist, in $42 \%$ of cells (Korotkova et al., 2005). Histamine $\mathrm{H}_{3}$ heteroreceptor function modulates cholinergic, GABA-ergic, as well as noradrenergic function (Panula et al., 2015) (Figure 1). 


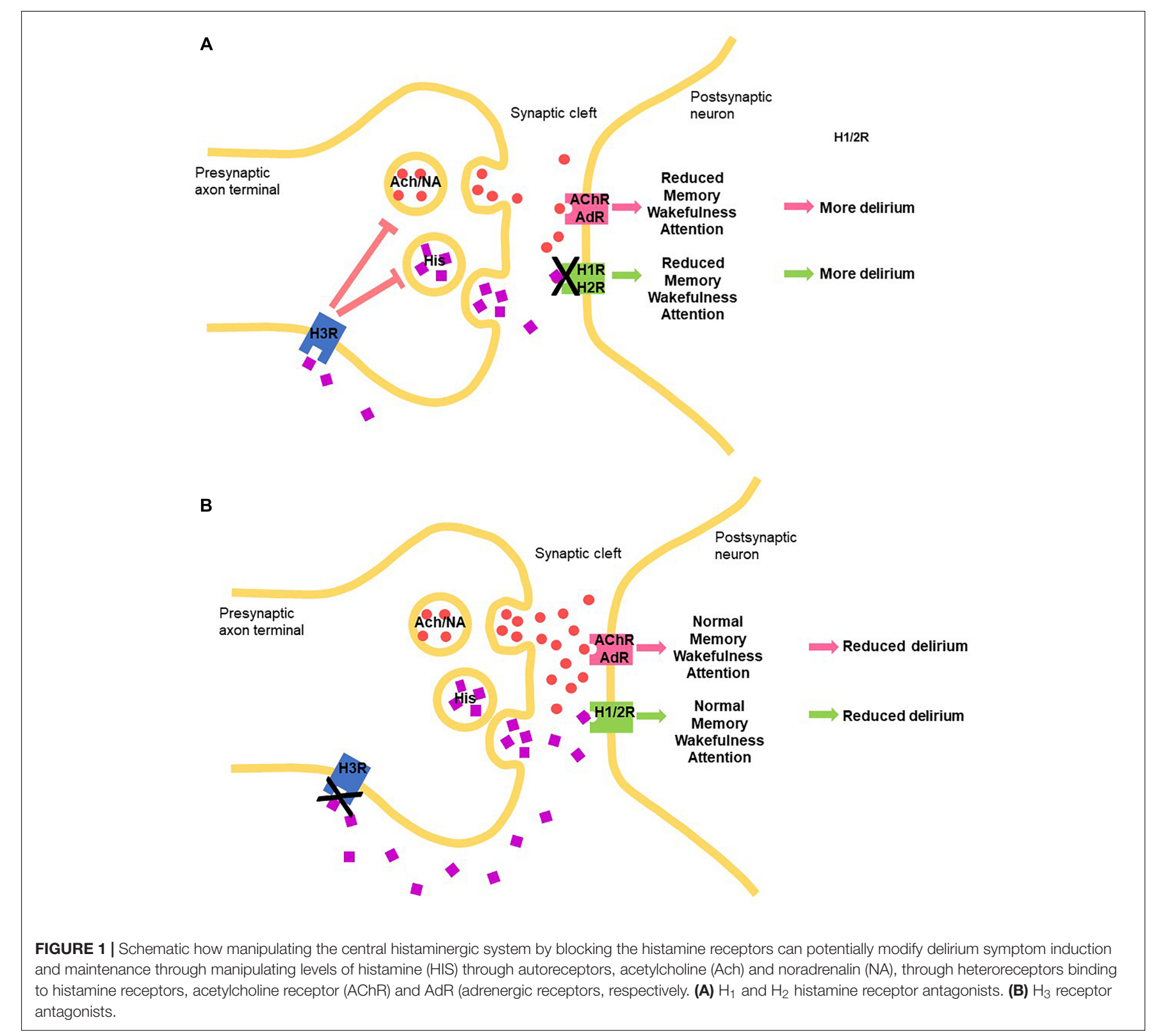

\section{HISTAMINE $\mathrm{H}_{1}$ RECEPTOR CNS PHYSIOLOGY}

Histamine $\mathrm{H}_{1}$ receptors occur throughout the CNS, with particular high densities in regions involved in arousal and waking, notably the thalamus and cortex, and neurochemically the cholinergic, noradrenergic, dopaminergic, and serotonergic nuclei. $\mathrm{H}_{1}$ receptor activation causes excitation in many brain regions (brain stem, thalamus, hypothalamus, cortex, amygdala, striatum) through $\mathrm{G}_{\mathrm{q} 11}$ protein and direct block of leak $\mathrm{K}^{+}$conductance or phospholipase $\mathrm{C}$, inositol trisphosphate $\left(\mathrm{IP}_{3}\right)$, and diacylglycerol (DAG) mediation (discussed in Obara et al., 2019). $\mathrm{IP}_{3}$ releases $\mathrm{Ca}^{2+}$ from internal stores and activates a number of $\mathrm{Ca}^{2+}$-dependent processes, including the opening of a cation channel of the transient receptor potential canonical (TRPC) type or stimulation of a $\mathrm{Na}^{+}-\mathrm{Ca}^{2+}$-exchanger. Furthermore, the elevated intracellular $\mathrm{Ca}^{2+}$ can stimulate NO synthase and, consequently, guanylate cyclase. On the other hand, $\mathrm{Ca}^{2+}$-dependent $\mathrm{K}^{+}$channels can be opened, leading to hyperpolarization and inhibition, for instance, in hippocampal pyramidal neurons.

\section{$\mathrm{H}_{2}$ HISTAMINE RECEPTOR CNS PHYSIOLOGY}

Histamine $\mathrm{H}_{2}$ receptors are also widely distributed in the mammalian brain (reviewed in Panula et al., 2015). The highest densities of histamine $\mathrm{H}_{2}$ receptors are found in the basal ganglia, hippocampus, amygdala and cerebral cortex, with 
modest expression levels in the cerebellum and hypothalamus (Panula et al., 2015; Monczor and Fernandez, 2016). A similar distribution of the histamine $\mathrm{H}_{2}$ receptor occurs in the brain of humans and rodents. $\mathrm{H}_{2}$ histamine receptor antagonists decreased significantly the hypothalamic NA content by $21-32 \%$. Activation of the histamine $\mathrm{H}_{2}$ receptor in the brain inhibits nerve cells and blocks long-lasting afterhyperpolarization and accommodation of firing in cortical and thalamic neurons (Haas and Reiner, 1988). However, if this afterhyperpolarization block continues for an protracted period, it can lead to potentiation of excitation in rodent and in human brain, resulting in enhanced synaptic plasticity (Brown et al., 1995). Therefore, $\mathrm{H}_{2}$ receptor antagonism can suppress plasticity. RT-PCR revealed that while mRNA for the $\mathrm{H}_{1}$ receptor was expressed in $77 \%$ of isolated LC neurons, mRNA for the $\mathrm{H}_{2}$ receptor was in $41 \%$ and $\mathrm{H}_{3}$ receptors in $29 \%$ of LC neurons. These findings underline the coordination between aminergic systems and suggest that the arousal induced by the histamine system could involve excitation of noradrenergic neurons in the LC (Korotkova et al., 2005).

\section{$\mathrm{H}_{3}$ RECEPTORS CNS PHYSIOLOGY}

$\mathrm{H}_{3}$ receptors, pre-synaptic inhibitory GPCRs, inhibit voltageactivated $\mathrm{Ca}^{2+}$ channels, on the terminals of histaminergic axons themselves (as an autoreceptor) and many types of neurons (heteroreceptor), which leads to reduced transmitter release of histamine, and acetylcholine, noradrenalin, serotonin, GABA, glutamate (heteroreceptors), respectively (reviewed in Panula et al., 2015). Despite $\mathrm{H}_{3}$ receptors being predominantly presynaptic receptors, regulating the release of neurotransmitters such as acetylcholine and histamine in most areas of the brain, in a particular part of the brain, namely the striatum, the vast majority of these receptors are actually postsynaptic, affecting signaling throughout the basal ganglia. Because the basal ganglia are centrally involved in several major neurological and psychiatric disorders, this aspect requires consideration. Constitutive activity in vivo and the possibility of dimerization shown in vitro for the $\mathrm{H}_{3}$ receptor has been reported (summarized in Panula et al., 2015), but relevance to physiological function of these functional and structural features and, therefore, to modulating delirium, is unclear.

\section{$\mathrm{H}_{4}$ RECEPTORS CNS PHYSIOLOGY}

A number of recent experimental studies suggest that systemic inflammation contributes to the pathophysiology of delirium in both elderly and post-trauma delirium. A common raised inflammatory cytokine linked to delirium in these studies is IL-6. Histamine via the histamine $\mathrm{H}_{4}$ receptor is known to play a key role in activating systemic inflammation through activation of microglia, mast cells and immune dendritic cells, with consequent production of proinflammatory factors TNF- $\alpha$ and, notably, IL-6 (Desai and Thurmond, 2011; Simon et al., 2011; Vasunilashorn et al., 2015; Ngo et al., 2017; Zhou et al., 2018). A rise in microglia $\mathrm{H}_{4} \mathrm{R}$ has been implicated in Parkinson's disease, in which delirium has been a recently recognized feature. This offers a possible role for the $\mathrm{H}_{4} \mathrm{R}$ in the neuroinflammatory components of delirium.

\section{HISTAMINE RECEPTOR SUBTYPE CONNECTIONS IN THE DELIRIUM CLINICAL SETTING AND WAKEFULLNESS}

\section{Histamine $\mathrm{H}_{1}$ and $\mathrm{H}_{2}$ Receptors}

Drug-induced delirium is often seen in clinical practice. Even before it was discovered that histamine was a transmitter in the brain, first generation anti-histamines (i.e., $\mathrm{H}_{1}$ receptor antagonists) were noted historically to be sedatives (eg., Monnier et al., 1967). Interestingly, $\mathrm{H}_{1}$ receptor antagonists, for example, doxepin (at low concentrations), are making a comeback to treat primary insomnia (Yeung et al., 2015). Histamine and $\mathrm{H}_{1} \mathrm{Rs}$ are involved in maintaining arousal and cognition in humans, and that the severity of clinical symptoms is correlated to the amount of antihistamine that has penetrated into the brain (Tashiro et al., 2002). It was noted, as far back as the 1980s, that delirium was a rare side-effect of both $\mathrm{H}_{1}$ and $\mathrm{H}_{2}$ antagonists (reviewed in Yanai et al., 2017) (Table 1). First generation $\mathrm{H}_{1}$ anti-histamines significantly increased daytime sleepiness and nocturnal sleep quality. Some, including cetirizine and hydroxyzine, seemed to also have negative influences on mood states. Outpatients who received cetirizine and hydroxyzine treatments reported higher scores on the depression, anxiety, and fatigue sub-scales compared to those who received desloratadine, levocetirizine, and rupatadine (Clegg and Young, 2011). The sedating antihistamines are non-specific in their actions and often have marked anticholinergic effects. Features of overdose include tachycardia, blood pressure disturbances, dry mouth, ataxia, psychosis, convulsion and, notably, agitation (Clegg and Young, 2011).

The second generation CNS-sparing $\mathrm{H}_{1}$ antihistamine, betahistine is not normally known to induce delirium, but an investigation in a side-effects databases did reveal several cases in which delirium may have been present, even though the term, delirium, was not actually used. In this case, delirium was potentially due to the combination of an elevated betahistine plasma level and, significantly, a damaged blood-brain barrier due to cerebral infarctions, confirmed both by computed tomography (CT) and Magnetic resonance imaging (MRI) scans (Hoenders and Wilterdink, 2004). It is noted that caution is often required when prescribing antihistamine $\mathrm{H}_{1}$ antagonists for people at risk of delirium and considered individual patient assessment is recommended. In contrast, a small, recent study showed cyproheptadine, a first generation anti- $\mathrm{H}_{1}$ antihistamine, with its range of diverse effects was proposed to be a potential option for prevention of postoperative delirium. In this pilot study, cyproheptadine significantly decreased the incidence, but not severity of postoperative delirium (this may relate to its central-permeability). In contrast, the main negative feature of promethazine (another first generation $\mathrm{H}_{1}$ antihistamine) is 
TABLE 1 | The implication of histaminergic system and drugs to delirium.

\begin{tabular}{|c|c|c|c|c|}
\hline Drug & Selectivity & $\begin{array}{l}\text { CNS- } \\
\text { permeable? }\end{array}$ & $\begin{array}{l}\text { Effects on } \\
\text { delirium? }\end{array}$ & Reference \\
\hline Doxepin & $\mathrm{H}_{1}$ & Yes & unknown & Yeung et al., 2015 \\
\hline Cetirizine & $\mathrm{H}_{1}$ & Yes & possible & $\begin{array}{l}\text { Clegg and Young, } \\
2011\end{array}$ \\
\hline Hydroxyzine & $\mathrm{H}_{1}$ & Yes & possible & $\begin{array}{l}\text { Clegg and Young, } \\
2011\end{array}$ \\
\hline Desloratadine & $\mathrm{H}_{1}$ & No & No & $\begin{array}{l}\text { Clegg and Young, } \\
2011\end{array}$ \\
\hline Levocetirizine & $\mathrm{H}_{1}$ & No & No & $\begin{array}{l}\text { Clegg and Young, } \\
2011\end{array}$ \\
\hline Rupatadine & $\mathrm{H}_{1}$ & No & No & $\begin{array}{l}\text { Clegg and Young, } \\
2011\end{array}$ \\
\hline Betahistine & $\mathrm{H}_{1}$ & No & Mixed data & $\begin{array}{l}\text { Hoenders and } \\
\text { Wilterdink, } 2004\end{array}$ \\
\hline Cyproheptadine & $\mathrm{H}_{1}$ & Yes & $\begin{array}{l}\text { Decreased } \\
\text { incidence but } \\
\text { not severity }\end{array}$ & Page et al., 2009 \\
\hline Cimetidine & $\mathrm{H}_{2}$ & Yes & Possible & $\begin{array}{l}\text { Cantú and Korek, } \\
1991\end{array}$ \\
\hline Cimetidine & $\mathrm{H}_{2}$ & Yes & Yes & Nowak, 1980 \\
\hline Cimetidine & $\mathrm{H}_{2}$ & Yes & Yes & Fujii et al., 2012 \\
\hline Ranitidine & $\mathrm{H}_{2}$ & No & Unusual & Mauran et al., 2016 \\
\hline
\end{tabular}

delirium, the probability of which can be predicted from the dose ingested by the individual (Page et al., 2009).

Studies on the association between CNS negative symptoms (psychosis, agitation, hallucinations, mental status changes, disorientation, confusion, irritability, a greatly reduced level of consciousness or hostility all underpinning delirium) and $\mathrm{H}_{2}$ blockers have been explored previously. These reactions generally occur during the first 2 weeks of therapy and resolve within 3 days of drug withdrawal, although long term use in critical care or the community may prove problematical. The estimated incidence of CNS negative symptoms is $0.2 \%$ or less in outpatients, but significantly higher, 1.6 to $80 \%$ in long-term hospitalized patients.

CNS side effects such as mental confusion (major facet of delirium) develop in elderly patients and in patients with severe renal or hepatic impairment. Cimetidine is CNS-permeable in the elderly and critically ill patients (with compromised bloodbrain barrier). Cimetidine is frequently associated with these "delirium" reactions; however, no clear evidence exists that one $\mathrm{H}_{2}$ blocker is more likely than another to cause such a reaction (Cantú and Korek, 1991). It has been noted that for people at risk of delirium, certain drug combinations are to be prescribed with care. Caution is also required when prescribing antihistamine $\mathrm{H}_{2}$ antagonists for people at risk of delirium and a considered individual patient assessment is advocated. Many case studies have been reported to support this policy. One example was a "serious" case of severe mania leading to hospitalization in a 42 year-old alcohol-dependent 4 days after ranitidine introduction (Mauran et al., 2016). Histamine $\mathrm{H}_{2}$ receptor antagonists may also cause acute or chronic cognitive impairment. These effects are often associated with some of the $\mathrm{H}_{2}$-histamine receptor antagonists, eg., cimetidine (Tagamet) again, but are unusual with ranitidine (Zantac), potentially again due to their respective
CNS permeability (Mauran et al., 2016). An old study showed that that a large dose of $\mathrm{H}_{2}$-receptor antagonists (50-259 micrograms ivt) decreased hypothalamic NA content (Nowak, 1980). A comparison was made between two groups of patients in a small study who were treated with $\mathrm{H}_{2}$ antagonists or proton pump inhibitors (PPI group) for anastomotic ulcer prevention following surgical treatment of esophageal cancer. It was noted that the incidence of delirium was significantly lower in the PPI group than in the $\mathrm{H}_{2}$ group. Significantly, in the 11 patients from the $\mathrm{H}_{2}$ group who developed delirium, discontinuation of $\mathrm{H}_{2}$ antagonists resulted in a significant reduction in the delirium rate score. This study indicated that switch from $\mathrm{H}_{2}$ blockers to PPIs reduced delirium and, thus, providing an appropriate strategy to combat drug-induced delirium using antiulcer drugs (Fujii et al., 2012). The ventrolateral preoptic nucleus is a sleeppromoting nucleus located in the basal forebrain. A commonly used intravenous anesthetic, propofol, had been reported to induce sleep and augment the firing rate of neurons in ventrolateral GABAergic preoptic nucleus, but the underlining mechanism is yet to be clearly determined. Interestingly, the propofol-induced inhibition of inhibitory postsynaptic currents on noradrenalin-inhibited neurons have been shown to be mediated by histaminergic $\mathrm{H}_{1}$ and $\mathrm{H}_{2}$ receptors (Liu et al., 2017).

\section{Opioids and Histamine Interactions}

An interaction between histaminergic and opioidergic systems within the CNS was proposed three decades ago, suggesting that analgesia produced by opioids may be associated with release of histamine and the stimulation of histamine receptors at the supraspinal (central) level (Nishibori et al., 1985). Many more recent studies have shown that histamine receptor antagonists can modulate the analgesic action of opioids, however, the site and mode of action of this interaction differs between the spinal or supraspinal level, and depends on the subtype of histamine receptor (Mobarakeh et al., 2002, 2006, 2009; Stein et al., 2016). A series of studies have also shown than in $\mathrm{H}_{1} \mathrm{R}$ and $\mathrm{H}_{2} \mathrm{R}$ $\mathrm{KO}$ mice, morphine-induced antinociception was significantly augmented when compared to the wild-type controls in models of acute pain. Therefore, anti-histamines should be prescribed with caution in people at risk of delirium, but this should be tempered by the observation that untreated severe pain can itself trigger delirium.

\section{Rationale for Use of $\mathrm{H}_{3}$ Antagonists for Future Development?}

Cortical activation (EEG desynchronization) is one of the salient signs of wakefulness, attention and enhanced cognitive function, and requires high histaminergic, and cholinergic, noradrenergic, and serotonergic tones, controlled by $\mathrm{H}_{3}$ autoand heteroreceptor action, respectively. Arousal induced by the histamine system through the $\mathrm{H}_{3}$ histamine heteroreceptor blockade is believed to largely involve excitation of noradrenergic neurons in the LC. As discussed above, the Histamine $\mathrm{H}_{3}$ receptor is expressed on and controls a population of the TM histamine/GABA-ergic neurons which are co-active in parallel and their ascending histamine/GABA fibers release histamine 
and GABA onto the PFC. Glutamatergic pyramidal neurons in the PFC send excitatory projections back to the histamine neurons in the TMN, reinforcing wakefulness, attention and consciousness. Selective blockade of the $\mathrm{H}_{3}$-autoreceptor with an $\mathrm{H}_{3}$ receptor antagonist would be predictive to drive this positive reinforcement.

Histamine promotes wakefulness by tonic control over sleepgenerating mechanisms in the preoptic/anterior hypothalamus, and cholinergic neurons seem to be implicated. The role of histamine indicates that the histaminergic system also influences attention and learning and memory performance by modulating the release of $\mathrm{ACh}$, although some cognitive effects of histamine and histaminergic agents occur independent of ACh. $\mathrm{H}_{3} \mathrm{R}$ antagonists are well known to enhance cognition and rescue cognitive deficits in preclinical models and modulate neurotransmission (Chazot, 2010), through, in particular, acetylcholine $(\mathrm{ACh})$ release in the cortex and hippocampus, two key brain areas involved in memory processing. It has been recently shown that histamine $\mathrm{H}_{3}$ receptor antagonist/inverse agonists require the integrity of brain histamine system to successfully elicit physiological and procognitive effects in the mouse (Provensi et al., 2016). Perfusion of the TMN with the $\mathrm{H}_{3}$ inverse agonist/antagonist (ABT-239) differentially increased histamine release from the TMN, NBM, and PFC, but not from the STR or NAcc.

\section{REFERENCES}

Brown, R. E., Fedorov, N. B., Haas, H. L., and Reymann, K. G. (1995). Histaminergic modulation of synaptic plasticity in area CA1 of rat hippocampal slices. Neuropharmacology 34, 181-190. doi: 10.1016/0028-3908(94)0 0138-I

Cantú, T. G., and Korek, J. S. (1991). Central nervous system reactions to histamine-2 receptor blockers. Ann. Intern. Med. 114, 1027-1034. doi: 10.7326/ 0003-4819-114-12-1027

Chazot, P. L. (2010). Therapeutic potential of histamine H3 receptor antagonists in dementias. Drug News Perspect. 23, 99-103. doi: 10.1358/dnp.2010.23.2. 1475899

Clegg, A., and Young, J. B. (2011). Which medications to avoid in people at risk of delirium: a systematic review. Age Ageing 40, 23-29. doi: 10.1093/ageing/af q140

Desai, P., and Thurmond, R. L. (2011). Histamine H4 receptor activation enhances LPS-induced IL-6 production in mast cells via ERK and PI3K activation. Eur. J. Immunol. 41, 1764-1773. doi: 10.1002/eji.201040932

Egberts, A., Wijnbeld, E. H., Fekkes, D., van der Ploeg, M. A., Ziere, G., Hooijkaas, H., et al. (2018). Neopterin: a potential biomarker for delirium in elderly patients. Front. Neural Circuits 12:4.

Fujii, S., Tanimukai, H., and Kashiwagi, Y. (2012). Comparison, and analysis of delirium induced by histamine $\mathrm{H}_{2}$ receptor antagonists and proton pump inhibitors in cancer patients. Case Rep. Oncol. 5, 409-412. doi: 10.1159/ 000341873

Giannoni, P., Passani, M. B., Nosi, D., Chazot, P. L., Shenton, F. C., Medhurst, A. D., et al. (2009). Heterogeneity of histaminergic neurons in the tuberomammillary nucleus of the rat. Eur. J. Neurosci. 29, 2363-2374. doi: 10.1111/j.1460-9568.2009.06765.x

Haas, H. L., and Reiner, P. B. (1988). Membrane properties of histaminergic tuberomammillary neurones of the rat hypothalamus in vitro. J. Physiol. 399, 633-646. doi: 10.1113/jphysiol.1988.sp017100

Herling, S. F., Greve, I. E., Vasilevskis, E. E., Egerod, I., Bekker Mortensen, C., Møller, A. M., et al. (2018). Interventions for preventing Intensive care unit delirium in adults. Cochrane Database Syst. Rev. 11:CD009783. doi: 10.1002/ 14651858.CD009783.pub2
When administered locally, ABT-239 $\left(\mathrm{H}_{3}\right.$ receptor antagonist) again increased histamine release from the NBM, but not from the NAcc. As defined by their sensitivity to ABT-239, histaminergic neurons establish distinct pathways according to their terminal projections, and can differentially modulate neurotransmitter release in a brain region-specific manner (Munari et al., 2013; Provensi et al., 2016). This implies independent functions of subsets of histamine neurons according to their terminal projections, with relevant consequences for the development of specific compounds that affect only subsets of histamine neurones, thus increasing target specificity. The selective mode of action is currently believed to be due to the respective levels of presynaptic $\mathrm{H}_{3} \mathrm{Rs}$ expressed on the TMN and cholinergic neurons (Giannoni et al., 2009). This requires formal confirmation. Overall, we provide an anatomical, pharmacological and physiological rationale for developing a CNS-permeable $\mathrm{H}_{3}$ histamine receptor antagonist/inverse agonist as a strategy for combatting the range of components of delirium.

\section{AUTHOR CONTRIBUTIONS}

All authors listed have made a substantial, direct and intellectual contribution to the work, and approved it for publication.

Hoenders, H. J., and Wilterdink, J. (2004). Delirium in a 73-year-old man after many years of unwise use of betahistine. Ned. Tijdschr. Geneeskd. 148, 2338-2341.

Korotkova, T. M., Sergeeva, O. A., Ponomarenko, A. A., and Haas, H. L. (2005). Histamine excites noradrenergic neurons in locus coeruleus in rats. Neuropharmacology 49, 129-134. doi: 10.1016/j.neuropharm.2005. 03.001

Leslie, D. L., and Inouye, S. K. (2011). The importance of delirium: economic and societal costs. MPH J. Am. Geriatr. Soc. 59(Suppl. 2), S241-S243. doi: 10.1111/j.1532-5415.2011.03671.x

Lin, J. S., Anaclet, C., Sergeeva, O. A., and Haas, H. L. (2011). The waking brain: an update. Cell Mol. Life Sci. 68, 2499-2512. doi: 10.1007/s00018-011-0631-8

Liu, Y., Zhang, Y., Qian, K., Zhang, L., and Yu, T. (2017). Histaminergic H1 and $\mathrm{H} 2$ receptors mediate the effects of propofol on the noradrenalin-inhibited neurons in rat ventrolateral preoptic nucleus. Neurochem. Res. 42, 1387-1393. doi: 10.1007/s11064-017-2187-y

Maldonado, J. R. (2013). Neuropathogenesis of delirium: review of current etiologic theories and common pathways. Am. J. Geriatr. Psychiatry 21, 1190-1222. doi: 10.1016/j.jagp.2013.09.005

Maldonado, J. R. (2015). "Delirium," in Handbook of Consultation-Liaison Psychiatry, 2nd Edn, eds H. Leigh and J. Streltzer (New York, NY: Springer International Publishing), 157-187.

Mauran, A., Goze, T., Abadie, D., Bondon-Guitton, E., Chevrel, P., Schmitt, L., et al. (2016). Mania associated with ranitidine: a case report and review of literature. Fundam. Clin. Pharmacol. 30, 294-296. doi: 10.1111/fcp.12201

Mobarakeh, J. I., Sakurada, S., Hayashi, T., Orito, T., Okuyama, K., Sakurada, T., et al. (2002). Enhanced antinociception by intrathecally-administered morphine in histamine $\mathrm{H} 1$ receptor gene knockout mice. Neuropharmacology 42, 1079-1088. doi: 10.1016/S0028-3908(02)00058-8

Mobarakeh, J. I., Takahashi, K., Sakurada, S., Kuramasu, A., and Yanai, K. (2006). Enhanced antinociceptive effects of morphine in histamine $\mathrm{H} 2$ receptor gene knockout mice. Neuropharmacology 51, 612-622. doi: 10.1016/j.neuropharm. 2006.05.003

Mobarakeh, J. I., Takahashi, K., and Yanai, K. (2009). Enhanced morphineinduced antinociception in histamine $\mathrm{H} 3$ receptor gene knockout mice. Neuropharmacology 57, 409-414. doi: 10.1016/j.neuropharm.2009.06.036 
Monczor, F., and Fernandez, N. (2016). Current knowledge and perspectives on histamine $\mathrm{H} 1$ and $\mathrm{H} 2$ receptor pharmacology: functional selectivity, receptor crosstalk, and repositioning of classic histaminergic ligands. Mol. Pharmacol. 90, 640-648. doi: 10.1124/mol.116.105981

Monnier, M., Fallert, M., and Battacharya, I. C. (1967). The waking action of histamine. Experientia 23, 21-22. doi: 10.1007/BF02142244

Munari, L., Provensi, G., Passani, M. B., and Blandina, P. (2013). Selective brain region activation by histamine $\mathrm{H} 3$ receptor antagonist/inverse agonist ABT-239 enhances acetylcholine and histamine release and increases c-Fos expression. Neuropharmacology 70, 131-140. doi: 10.1016/j.neuropharm.2013.01.021

Ngo, L. H., Inouye, S. K., Jones, R. N., Travison, T. G., Libermann, T. A., Dillon, S. T., et al. (2017). Methodologic considerations in the design and analysis of nested case-control studies: association between cytokines and postoperative delirium. BMC Med. Res. Methodol. 17:88. doi: 10.1186/s12874-017-0359-8

Nishibori, M., Oishi, R., Itoh, Y., and Saeki, K. (1985). Morphine-induced changes in histamine dynamics in mouse brain. Neurochem. J. 45, 719-724. doi: 10.1111/ j.1471-4159.1985.tb04051.x

Nowak, J. Z. (1980). Effects of histamine H1- and H2-receptor antagonists on dopamine, noradrenaline and serotonin systems in rat brain. Pol. J. Pharmacol. Pharm. 32, 451-461.

Obara, I., Telezhkin, V., Alrashdi, I., and Chazot, P. L. (2019). Histamine receptors and neuropathic pain relief. BJP (in press).

Oh, J., Petersen, C., Walsh, C. M., Bittencourt, J. C., Neylan, T. C., and Grinberg, L. T. (2018). The role of co-neurotransmitters in sleep and wake regulation. Mol. Psychiatry doi: 10.1038/s41380-018-0291-2 [Epub ahead of print].

Page, C. B., Duffull, S. B., Whyte, I. M., and Isbister, G. K. (2009). Promethazine overdose: clinical effects, predicting delirium and the effect of charcoal. QJM 102, 123-131. doi: 10.1093/qjmed/hcn 153

Panula, P., Chazot, P. L., Cowart, M., Gutzmer, R., Leurs, R., Liu, W. L., et al. (2015). International union of basic and clinical pharmacology. XCVIII. Histamine receptors. Pharmacol. Rev. 67, 601-655. doi: 10.1124/pr.114. 010249

Parmentier, R., Ohtsu, H., Djebbara-Hannas, Z., Valatx, J. L., Watanabe, T., and Lin, J. S. (2002). Anatomical, physiological, and pharmacological characteristics of histidine decarboxylase knock-out mice: evidence for the role of brain histamine in behavioral and sleep-wake control. J. Neurosci. 22, 7695-7711. doi: 10.1523/JNEUROSCI.22-17-07695.2002

Provensi, G., Costa, A., Passani, M. B., and Blandina, P. (2016). Donepezil, an acetylcholine esterase inhibitor, and ABT-239, a histamine H3 receptor antagonist/inverse agonist, require the integrity of brain histamine system to exert biochemical and procognitive effects in the mouse. Neuropharmacology 70, 131-140. doi: 10.1016/j.neuropharm.2013.01.021

Richards-Belle, A., Mouncey, P. R., Wade, D., Brewin, C. R., Emerson, L. M., Grieve, R., et al. (2018). Psychological outcomes following a nurse-led preventative psychological intervention for critically ill patients (POPPI): protocol for a cluster-randomised clinical trial of a complex intervention. BMJ Open 8:e020908. doi: 10.1136/bmjopen-2017-020908
Simon, T., Laszlo, V., Lang, O., Buzas, E., and Falus, A. (2011). Histamine regulates relevant murine dendritic cell functions via $\mathrm{H} 4$ receptor. Front. Biosci. 3:1414-1424. doi: 10.2741/e343

Stein, T., Souza-Silva, E., Mascarin, L., Eto, C., Fin, F. E., and Tonussi, C. R. (2016). Histaminergic pharmacology modulates the analgesic and anti-dematogenic effects of spinally injected morphine. Anesth. Analg. 123, 238-243. doi: 10.1213/ ANE.0000000000001326

Tashiro, M., Mochizuki, H., Iwabuchi, K., Sakurada, Y., Itoh, M., Watanabe, T., et al. (2002). Roles of histamine in regulation of arousal and cognition: functional neuroimaging of histamine $\mathrm{H} 1$ receptors in human brain. Life Sci. 72, 409-414. doi: 10.1016/S0024-3205(02)02276-2

Vasunilashorn, S. M., Ngo, L., Inouye, S. K., Libermann, T. A., Jones, R. N., Alsop, D. C., et al. (2015). Cytokines and postoperative delirium in older patients undergoing major elective surgery. Dement Geriatr. Cogn. Disord. 39, 116-124.

Wade, D. M., Moon, Z., Windgassen, S., Harrison, A., Morris, L., and Weinman, J. (2015). Non-pharmacological interventions to reduce ICU-related psychological distress: a systematic review. Minerva Anestesiol. 82, 465-478.

Wade, D. M., Mouncey, P. R., Richards-Belle, A., Wulff, J., Harrison, D. A., Sadique, M. Z., et al. (2019). Effect of a nurse-led preventive psychological intervention on symptoms of posttraumatic stress disorder among critically ill patients: a randomized clinical trial. JAMA 321, 665-675. doi: 10.1001/jama.2019.0073

Yanai, K., Yoshikawa, T., Yanai, A., Nakamura, T., Iida, T., Leurs, R., et al. (2017). The clinical pharmacology of non-sedating antihistamines. Pharmacol. Ther. 178, 148-156. doi: 10.1016/j.pharmthera.2017.04.004

Yeung, W. F., Chung, K. F., Yung, K. P., and Ng, T. H. (2015). Doxepin for insomnia: a systematic review of randomized placebo-controlled trials. Sleep Med. Rev. 19, 75-83. doi: 10.1016/j.smrv.2014.06.001

Yu, X., Franks, N. P., and Wisden, W. (2018). Sleep and sedative states induced by targeting the histamine and noradrenergic systems. Front. Neural Circuits. 12:4. doi: 10.3389/fncir.2018.00004

Zhou, P., Homberg, J. R., Fang, Q., Wang, J., Li, W., Meng, X., et al. (2018). Histamine-4 receptor antagonist JNJ7777120 inhibits pro-inflammatory microglia and prevents the progression of Parkinson-like pathology and behaviour in a rat model. Brain Behav. Immun. 76, 61-73. doi: 10.1016/j.bbi. 2018.11.006

Conflict of Interest Statement: The authors declare that the research was conducted in the absence of any commercial or financial relationships that could be construed as a potential conflict of interest.

Copyright (c) 2019 Chazot, Johnston, Mcauley and Bonner. This is an open-access article distributed under the terms of the Creative Commons Attribution License (CC BY). The use, distribution or reproduction in other forums is permitted, provided the original author(s) and the copyright owner(s) are credited and that the original publication in this journal is cited, in accordance with accepted academic practice. No use, distribution or reproduction is permitted which does not comply with these terms. 